\title{
Introduction - Corporate Social Responsibility
}

\section{Vanisha H. Sukdeo*}

When I started compiling the list of contributors for the special issue I wanted to make sure that it was a diverse group with varying research interests that all fell under the broad umbrella of corporate governance and Corporate Social Responsibility [CSR]. This issue includes scholars from Canada as well as Australia. In 2004, the Supreme Court of Canada [SCC] handed down the Peoples ${ }^{1}$ decision which expanded on Section 122 of the Canada Business Corporations Act [CBCA]. The Court found that "the fiduciary duty under s. 122(1)(a) of the $C B C A$ requires directors and officers to act in good faith and honestly vis-à-vis the corporation. Directors and officers will not be held to be in breach of the duty of care under s. 122(1) $(b)$ of the $C B C A$ if they act prudently and on a reasonably informed basis." 2 In 2008, the SCC handed down the decision in $B C E^{3}$. Building on Peoples, $B C E$ stands for the proposition that Directors and Officers have obligations to stakeholder groups beyond shareholders. ${ }^{4}$ To understand the changes made in Canada since Peoples in 2004 and $B C E$ in 2008, there has to be an appreciation of the movement towards social justice and the ability of all areas of law to bend towards justice and progress. Corporate Law is often thought to fall under the term "black letter law" such as Torts in first year law school as these are areas of law that have their foundations in the neighbour principle from Donoghue. These tend to be thought of as antiquated notions about duty of care and other less trendy topics compared to the trendy topics of Artificial Intelligence and Bitcoin. Corporate Law can be used to help advance the interests of the less powerful through harnessing the power of the corporation and reforming the discussion from being just about shareholders to being about all stakeholders. To return to the topic of neighbour - the discussion becomes oriented towards whether someone in the same city is your neighbour and whether those concepts can be stretched to include those who mine for conflict minerals in Africa. Are they neighbours to a Canadian? If so, what duty is owed to them? How can duties be built to ensure that the law protects all and not just a select few? The articles included in this special issue seek answers to those questions.

Professor Benjamin J. Richardson examines how the concept of "aesthetic" can be used to examine greenwashing, consumer culture as well as culture jamming. He examines how consumers are sold a version of corporations helping the environment which at times may be self-serving. Corporations often push for self-regulation to avoid state regulation. So too does that hold for environmental protections. If corporations are able to posit themselves as eco-champions then they may be able to dissuade governments from bringing in new environmental protections. Why bother forcing corporations to help the environment when so many corporations are successfully branding themselves as being eco-friendly already? This

\footnotetext{
* Vanisha H Sukdeo is a lawyer, Course Director, and Ph.D. Candidate at Osgoode Hall Law School in Toronto, Ontario. She is the author of two books - Regulation and Inequality at Work (New York: Routledge, 2018) and Corporate Law, Codes of Conduct and Workers' Rights (New York: Routledge, 2019). Vanisha has also published articles and book chapters on a range of topics from corporate law to labour \& employment law. Vanisha also has a forthcoming book that is set for publication in 2020 .

1 Peoples Department Stores v. Wise, 2004 SCC 68.

2 Vanisha Sukdeo, Corporate Law, Codes of Conduct and Workers'Rights (New York: Routledge, 2019$)$, at 83.

3 BCE Inc. v. 1976 Debentureholders, 2008 SCC 69.

4 For a more in depth summary of both Peoples and BCE please see, Sukdeo, supra note 2 at 83.
} 
helps to position organizations such as Greenpeace as being too radical compared to the corporation that is trying to save the planet.

Professors Janet Austin and Sulette Lombard write about whistleblowing and the phenomenon of paying whistleblowers. They examine the differences between the Securities and Exchange Commission [SEC] in America, which is Federal, and the Ontario Securities Commission [OSC] which is provincial. The prospect of a national securities regulator in Canada may bring about a change to the program offered by the OSC. According to Austin and Lombard the SEC paid $\$ 160$ million to whistleblowers but save $\$ 975$ million. So the cost of paying the whistleblowers is offset by the money saved. Also, the authors examine the differences between corporate gatekeepers such as bankers and lawyers and whistleblowers. The role of in-house counsel as gatekeeper is different from external counsel as gatekeeper but both play vital roles in making sure that corporate wrongdoing is not allowed to thrive.

Professor Fenner Stewart traces CSR back to the origins of liberalism itself and discusses theorists who underpin modern thought like Michel Foucault and his determination of power. To understand the corporation and its manifestation of power it is important to study Foucault. CSR acts to layer the governance of the state with governance mechanisms like soft law and this ultimately combats the stronghold on power by the state. If the state gives away power to the corporation then it is simply undermining its very existence as the first and final source of governance and regulation. Why should the state regulate when the corporation can? Unless the notion of corporations running the entire system alone is challenged and stopped then that might be the end result. Berle and Means warned about the rise of the modern corporation and it superseding the power and wealth of the nation state. Stewart seems more optimistic about the promise of CSR to help increase corporate accountability and perhaps rein in the power of the corporation.

Professor Carol Liao, and articling students Elsir U. Tawfik, and Pat Teichreb discuss the emergence of social enterprise. The discussion focuses on the B Corporation which is a certification scheme run by $\mathrm{B}$ Lab and the authors examine how B Lab may be pushing the B Corporation. The issue arises as to what role B Lab should play in guiding the rise of the B Corporation. The rise of hybrid corporations and corporations that have legislatively defined "social benefit" purposes has moved the role of the corporation into a more mainstream conversation about what that role should be.

Do corporations have obligations to act in the interest of the public or just their shareholders? If $B C E$ means that Directors and Officers have to "consider interests" of stakeholders then who counts as a "stakeholder"? The articles weave together themes about the purpose of the corporation and how CSR has helped to reframe and potentially reform the corporation within society. If the corporation is to continue to thrive then it has to posit itself within the framework of being of social value as scholars continue to push for greater transparency and accountability of all corporations. And not just accountability to their home country but to the countries in which they operate, source their material, and manufacture their products. Stakeholders have achieved greater prominence through using both the courtroom as a vehicle for greater access to justice but also media coverage of the activities of the corporation. Greater attention is being paid to corporate activities on a world stage and greater attention may lead to corrections in behaviour. Only through continued pressure to be more socially responsible will corporations stay the course and perhaps provide more protection to the less powerful. 